\title{
Pathogenicity of Miamiensis avidus (syn. Philasterides dicentrarchi), Pseudocohnilembus persalinus, Pseudocohnilembus hargisi and Uronema marinum (Ciliophora, Scuticociliatida)
}

\author{
Jun-Young Song ${ }^{1}$, Shin-Ichi Kitamura ${ }^{1,4}$, Myung-Joo Oh ${ }^{1}$, Hyun-Sil Kang ${ }^{2}$, \\ Je-hee Lee ${ }^{2}$, Shin-Ji Tanaka ${ }^{3}$, Sung-Ju Jung ${ }^{1, *}$
}

\author{
${ }^{1}$ Department of Aqualife Medicine, Chonnam National University, Chonnam 550-749, South Korea \\ ${ }^{2}$ Department of Marine Biotechnology, Cheju National University, Jeju-Do 690-756, South Korea \\ ${ }^{3}$ Fisheries Research Division, Mie Prefectural Science and Technology Promotion Center, Mie 517-0404, Japan
}

${ }^{4}$ Present address: Center for Marine Environmental Studies (CMES), Ehime University, Bunkyo-cho 3, Matsuyama 790-8577, Japan

\begin{abstract}
The scuticociliates Miamiensis avidus (syn. Philasterides dicentrarchi), Pseudocohnilembus persalinus, Pseudocohnilembus hargisi and Uronema marinum were cloned and identified using morphological characteristics and the small subunit ribosomal RNA gene (SSU rRNA). M. avidus strains YS1, WS1, YK1 and JJ3 from southern coastal areas and Jeju Island in Korea were pathogenic to olive flounder Paralichthys olivaceus (80 to $100 \%$ mortality in 8 to $10 \mathrm{~g}$ fish) when inoculated intraperitoneally (i.p.) with 1.0 to $1.4 \times 10^{6}$ ciliates fish $^{-1}$. Mortality was lower (10 to $45 \%$ ) when the inoculum was 1.0 to $1.4 \times 10^{4}$ ciliates fish ${ }^{-1}$ in the i.p.-injected group. The M. avidus strains of YS1, WS1, YK1 and JJ3 caused 60 to $100 \%$ mortality by immersion infection with 3.2 to $4.2 \times 10^{3} \mathrm{ml}^{-1}$ in 8 to $10 \mathrm{~g}$ fish and 3.0 to $4.0 \times 10^{3} \mathrm{ml}^{-1}$ in 30 to $40 \mathrm{~g}$ fish. M. avidus strain Mie0301 from the Mie prefecture in Japan caused $70 \%$ mortality by immersion infection with $4.4 \times 10^{3} \mathrm{ml}^{-1}$ in 30 to $40 \mathrm{~g}$ fish. The predominant sign was severe abdominal distension in i.p.-injected fish, and extensive ulcer lesions in the skeletal muscle in immersion-infected fish. Numerous ciliates were observed in the ascetic fluid, ulcers, haemorrhagic lesions, gills and brain of infected fish. However, P. persalinus (strain SCL-A), P. hargisi (strain SCL-B) and U. marinum (strain JK3) showed less than $30 \%$ mortality from both i.p. and immersion challenges, with no ciliate invasion in the skin, gills or brain. $M$. avidus-infected fish showed many ciliates in gills, fins, skin muscle, brain and intestine accompanied by necrosis and haemorrhages. However, no histological changes were observed in P. persalinus--, P. hargisi- or U. marinum-infected fish.
\end{abstract}

KEY WORDS: Pathogenicity · Scuticociliatida · Miamiensis avidus · Philasterides dicentrarchi · Pseudocohnilembus persalinus · Pseudocohnilembus hargisi • Uronema marinum • Olive flounder • Paralichthys olivaceus

Resale or republication not permitted without written consent of the publisher

\section{INTRODUCTION}

Scuticociliates are regarded as serious pathogens in marine aquaculture worldwide. They cause mass mortalities in fish such as olive flounder Paralichthys olivaceus (Yoshinaga \& Nakazoe 1993, Jee et al. 2001,
Kim et al. 2004a,b, Jung et al. 2005), turbot Scophthalmus maximus (Dyková \& Figueras 1994, Sterud et al. 2000, Iglesias et al. 2001, Puig et al. 2007), sea bass Dicentrarchus labrax (Dragesco et al. 1995), southern bluefin tuna Thunnus maccoyii (Munday et al. 1997), seahorse Hippocampus erectus (Thompson \& Moewus 
1964) and silver pomfret Pampus argenteus (Azad et al. 2007).

Commercially significant occurrences of scuticociliatosis in olive flounder in Korea were first noted in 1990 (Chun 2000). The ciliates occurred in the gills, skin, heart, brain, muscles and visceral organs including the intestine. Scuticociliatosis is highly histophagous and destroys infected tissues. The causative agents of scuticociliatosis in the olive flounder in Korea with the same clinical signs mentioned above have been isolated and identified as Uronema marinum (Jee et al. 2001), Pseudocohnilembus persalinus (Kim et al. 2004b), Philasterides dicentrarchi (Kim et al. 2004a) and Miamiensis avidus (Jung et al. 2005). In addition, a very similar disease with high mortality caused by an unidentified scuticociliate in olive flounder juveniles was also reported in Japan (Yoshinaga \& Nakazoe 1993). However, it is not clear if all the species of scuticociliates cause mortalities with similar clinical signs in olive flounder.

In a previous study, using small subunit ribosomal RNA gene (SSU rRNA) and morphological characteristics, we confirmed Miamiensis avidus as a senior synonym of Philasterides dicentrarchi (Jung et al. 2007). Moreover, pathogenicity of the $M$. avidus YS1 strain was confirmed by experimental infections. In the present study, we experimentally infected olive flounder with $M$. avidus, Uronema marinum, Pseudocohnilembus persalinus and Pseudocohnilembus hargisi to determine their pathogenicity; results suggest that $M$. avidus is the main cause of mortality in olive flounder.

\section{MATERIALS AND METHODS}

Ciliate collection. Scuticociliates were isolated from 7 olive flounder at different farms. One strain (JK3) was isolated from the rotifer Brachionus plicatilis in an olive flounder hatchery (Table 1). All infected fish showed typical signs of scuticociliatosis such as severe ulcers and haemorrhages in the skeletal muscle.
Culture. The brain and skin ulcer lesions of infected fish were dissected and washed 3 times in EMEM containing antibiotics (500 IU ml ${ }^{-1}$ penicillin and $500 \mu \mathrm{g}$ streptomycin). A small piece of tissue was inoculated into $25 \mathrm{~cm}^{2}$ tissue-culture flasks with Chinook salmon embryo (CHSE-214) cells. The CHSE-214 cells were cultured in EMEM, supplemented with $10 \%$ fetal bovine serum (FBS), penicillin (50 IU ml-1) and streptomycin $\left(50 \mu \mathrm{g} \mathrm{ml}^{-1}\right)$ at $20^{\circ} \mathrm{C}$. The antibiotic concentration was increased 10 times for skin samples (500 IU $\mathrm{ml}^{-1}$ penicillin and $500 \mu \mathrm{g} \mathrm{ml}^{-1}$ streptomycin). An isolate (JK3) was originated from rotifers, which are a food organism for olive flounder larvae. Rotifers containing scuticociliates were inoculated into $25 \mathrm{~cm}^{2}$ tissue-culture flasks with CHSE-214 cells supplemented with 10 times the antibiotic concentrations.

Cloning. After 3 to $7 \mathrm{~d}$ of culture, each isolate was cloned 5 times using the limiting dilution method with some modifications (Goding 1993). Briefly, a series of dilutions was made from the original culture and cell numbers were adjusted to a concentration of 10 ciliates $\mathrm{ml}^{-1}$. Then, $50 \mu \mathrm{l}$ of the diluted suspension was inoculated into each well ( 0.5 cells well $\left.{ }^{-1}\right)$ of a 96 well tissueculture plate containing $100 \mu \mathrm{l}$ of CHSE-214 cell suspension.

Identification. Morphological studies were made using the silver carbonate and 'wet' silver nitrate methods described by Foissner (1991). For the silver carbonate stain, ciliates were fixed in $5 \%$ formalin, washed and then stained in Fernandez-Galiano's fluid on a pre-heated $\left(60^{\circ} \mathrm{C}\right)$ hot plate approximately 5 min until the solution turned golden brown. The reaction was terminated using $5 \%$ sodium thiosulfate. For the silver nitrate stain, concentrated ciliates were fixed in centrifuge tubes with Champy's fixative, and then washed into DaFano's fixative. Slides were warmed on a slide warmer set at 35 to $45^{\circ} \mathrm{C}$. A tiny drop of concentrated ciliate was placed on a warm slide and embedded in a thin gelatin layer. The liquefied preparation was solidified by cooling on a moist cold surface and then rinsed with distilled water. Slides were placed in a cold $3 \%$

Table 1. Scuticociliates isolated from olive flounder used in the infection experiments. Uronema marinum was isolated from the rotifer Brachionus plicatilis in an olive flounder hatchery. Dates are given as $\mathrm{dd} / \mathrm{mm} / \mathrm{yyyy}$

\begin{tabular}{|lcccc|}
\hline Species & Strain & Sampling date & Sampling location & Isolated origin \\
\hline Miamiensis avidus & YS1 & $22 / 05 / 1999$ & Yosu & Brain \\
& WS1 & $20 / 08 / 2003$ & Wando & Brain \\
& YK1 & $26 / 11 / 2003$ & Youngkwang & Brain \\
& JJ3 & $29 / 07 / 2004$ & Jeju & Brain \\
Pseudocohnilembus persalinus & Mie0301 & $28 / 11 / 2003$ & Brain \\
Pseudocohnilembus hargisi & SCL-A & $21 / 10 / 2003$ & Wando & Skin ulcer \\
Uronema marinum & SCL-B & $21 / 10 / 2003$ & Jeju ulcer & Rotifer \\
\hline
\end{tabular}


silver nitrate bath for $1 \mathrm{~h}$. After washing with cold distilled water, slides were irradiated for 3 to $5 \mathrm{~h}$ using ultraviolet lights on a clean bench until the gelatin turned golden brown. Slides were subsequently dehydrated, cleared and mounted.

SSU rRNA analysis was carried out as described previously (Jung et al. 2005). Briefly, $1 \mathrm{ml}$ of cultured ciliates was harvested by centrifugation at $2000 \times g$ for $5 \mathrm{~min}$. The pellet was lysed in a solution of $170 \mu \mathrm{l}$ TrisEDTA buffer, $20 \mu \mathrm{l}$ Proteinase $\mathrm{K}\left(20 \mathrm{mg} \mathrm{ml}^{-1}\right.$; TaKaRa) and $10 \mu \mathrm{l} 10 \%$ sodium dodecyl sulfate (SDS). After incubation at $55^{\circ} \mathrm{C}$ for $2 \mathrm{~h}$, nucleic acids were extracted using TRIzol (Invitrogen) and chloroform. The eukaryotic universal primers A (5'-ACC TGG TTG ATC CTG CCA GT-3') (primer 1) and B (5'-TGA TCC TTC TGC AGG TTC ACC TAC-3') (primer 6), were used to amplify the full-length eukaryotic SSU rDNA gene, followed by thermal cycling with 40 amplification cycles $\left(94^{\circ} \mathrm{C}\right.$ for $30 \mathrm{~s}, 50^{\circ} \mathrm{C}$ for $30 \mathrm{~s}$ and $72^{\circ} \mathrm{C}$ for $\left.2 \mathrm{~min}\right)$. PCR products were purified using the QIAquick Gel Extraction Kit (Qiagen) and cloned into pCR-2.1 T-vector (Invitrogen). Escherichia coli TOP10 (Invitrogen) competent cells were transformed for plasmid propagation according to the manufacturer's protocol. Plasmid DNA was extracted from cultured E. coli TOP10 and used for sequencing. Sequencing was performed in an automated ABI PRISM 310 DNA sequencer (PE Biosystems). DNA samples were sequenced in both directions and from several separate amplifications with terminal primers (primers $1 \& 6$ ) and internal primers. The internal primers used were primer $2\left(5^{\prime}-\mathrm{CTA}\right.$ TCA GCT TTC GAT GGT-3'), primer 3 (5'-GTA GGC TCT TTA CCT TGA-3'), primer 4 (5'-CAA ATC ACT CCA CCA ACT-3') and primer 5 (5'-ACG ACT TCT CCT TCC TCT-3'). Sequences were verified by forward and reverse comparisons and assembled and edited using Genetyx Win Ver. 5.1 software.

Fish. All the fish used in the experimental infection were obtained from a fish farm in the Goheung area.
Five randomly selected fish were confirmed to be free from pathogens; the absence of parasites was confirmed by microscopic observation, bacteria by isolation on brain heart infusion agar (BHIA) (Difco) and viruses by isolation in CHSE-214 cells. Fish were held in laboratory conditions for $10 \mathrm{~d}$ until experimental infection. Water was maintained at approximately $20^{\circ} \mathrm{C}$, and was constantly aerated for the duration of the experiment.

Infection experiment. Intraperitoneal injection: Ciliates collected from the $75 \mathrm{~cm}^{2}$ tissue-culture flasks were centrifuged at $500 \times g$ for $10 \mathrm{~min}$ at room temperature. One ml EMEM was added into the cell pellet and the resuspended ciliates were counted using a haemocytometer. Twenty fish (8 to $10 \mathrm{~g}$ ) in each tank were each injected intraperitoneally with $50 \mu \mathrm{l}$ of 1.0 to $1.4 \times 10^{4}$ or $10^{6} \mathrm{cells} \mathrm{fish}^{-1}$ of YS1, WS1, YK1, JJ3, SCL-A, SCL-B and JK3 (Table 2). Each control fish was injected with $50 \mu$ l EMEM. After inoculation, the fish were held in 201 tanks at about $20^{\circ} \mathrm{C}$. Half of the water was changed daily, and the fish were monitored for $24 \mathrm{~d}$. Dead and moribund fish were collected and the skin, gills and brain were examined using a wet mount preparation to confirm the presence of parasites.

Immersion: There were 2 experimental infections by immersion. In the first experiment, 10 fish weighing 8 to $10 \mathrm{~g}$ were used in each tank and the strains employed as a challenge were YS1, YK1, WS1, JJ3, SCL-A and SCL-B. The ciliate numbers were adjusted in the range of 3.2 to $4.4 \times 10^{3} \mathrm{ml}^{-1}$ (Table 2). The food source bacteria were counted in BHIA, and numbered $4.2 \times 10^{2}$ and $1.5 \times 10^{3}$ cells ml $^{-1}$ for SCL-A and SCL-B, respectively. Seawater in the fish tanks was drained to a volume of 51 and then prepared scuticociliates were immersed at the concentrations mentioned above. The control tank was used in a similar manner using $3 \mathrm{ml}$ EMEM containing no ciliates. After $3 \mathrm{~d}$, the tank volumes were returned to $20 \mathrm{l}$.

Table 2. Challenge doses for the experimental infection. nd: not determined. For intraperitoneal injection experiments, doses are in ciliates fish $^{-1}$; for immersion experiments, doses are in ciliates $\mathrm{ml}^{-1}$

\begin{tabular}{|lccccc|}
\hline \multirow{2}{*}{ Species } & \multirow{2}{*}{ Strains } & \multicolumn{2}{c}{ Intraperitoneal injection } & \multicolumn{2}{c|}{ Immersion } \\
& & Low & High & 1st & 2nd \\
\hline Miamiensis avidus & YS1 & $1.4 \times 10^{4}$ & $1.4 \times 10^{6}$ & $4.0 \times 10^{3}$ & $4.0 \times 10^{3}$ \\
& WS1 & $1.0 \times 10^{4}$ & $1.0 \times 10^{6}$ & $3.4 \times 10^{3}$ & $3.0 \times 10^{3}$ \\
& YK1 & $1.1 \times 10^{4}$ & $1.1 \times 10^{6}$ & $3.2 \times 10^{3}$ & $3.4 \times 10^{3}$ \\
& JJ3 & $1.4 \times 10^{4}$ & $1.4 \times 10^{6}$ & $4.2 \times 10^{3}$ & $3.8 \times 10^{3}$ \\
& Mie0301 & nd & nd & nd & $4.4 \times 10^{3}$ \\
Pseudocohnilembus persalinus & SCL-A & $1.3 \times 10^{4}$ & $1.3 \times 10^{6}$ & $3.6 \times 10^{3}$ & $5.2 \times 10^{3}$ \\
Pseudocohnilembus hargisi & SCL-B & $1.0 \times 10^{4}$ & $1.0 \times 10^{6}$ & $4.4 \times 10^{3}$ & $3.4 \times 10^{3}$ \\
Uronema marinum & JK3 & $1.0 \times 10^{4}$ & $1.0 \times 10^{6}$ & nd & $2.6 \times 10^{3}$ \\
& & & & & \\
\hline
\end{tabular}


For the second experiment, fish weighing 30 to $40 \mathrm{~g}$ were infected with the strains listed in Table 2 at concentrations ranging from 2.6 to $5.2 \times 10^{3}$ cells $\mathrm{ml}^{-1}$. The Miamiensis avidus Mie0301 strain from Japan and the Uronema marinum JK3 strain isolated from rotifers were included (Table 2). Food bacteria of $4.2 \times 10^{2}$, $4.4 \times 10^{2}$ and $1.8 \times 10^{5}$ cells $\mathrm{ml}^{-1}$ were contained in SCL-A, SCL-B and JK3, respectively. Other challenge conditions were comparable with those used in the first immersion experiment.

Dead and moribund fish were removed from the tank and clinical signs and mortality for the duration of the experiment were recorded; ciliates were examined using a wet mount preparation.

Histopathological analysis. The skin, gill, brain, kidney, liver, spleen, heart, stomach and intestine from all individual moribund fish were removed and fixed in $10 \%$ neutral formalin. After fixation, the specimens were embedded in paraffin and sectioned with a microtome at 4 to $5 \mu \mathrm{m}$. The sections were then stained with haematoxylin and eosin (H\&E) and Giemsa.

Statistical analysis. We used the JMP statistical program package for statistical analyses (SAS Institute). Survival curves were compared using the generalized Wilcoxon rank sum and log-rank tests. Wilcoxon pvalues are shown; $\mathrm{p} \leq 0.05$ was considered significant.

\section{RESULTS}

\section{Isolation}

Axenic culture of ciliates obtained from a piece of brain was successful in CHSE-214 cells in EMEM with $10 \%$ FBS. However, ciliates from skin lesions often encountered bacterial contamination in spite of high antibiotic concentrations (500 IU ml ${ }^{-1}$ penicillin and $500 \mu \mathrm{g} \mathrm{ml} \mathrm{m}^{-1}$ streptomycin). Skin cultures were discarded when axenic culture from the brain tissue of the same fish was successful. Two ciliate cultures from skin lesions from 2 different fish farms were maintained because ciliates did not grow in the brain sample. From rotifers, scuticociliates were obtained in CHSE-214 cells but multiplication was poor.

\section{Cloning}

From the brain of olive flounder, 5 strains, YS1, WS1, YK1, JJ3 and Mie0301, were cloned (Table 1). Two culture flasks inoculated a piece of skin ulcer containing 2 morphologically different scuticociliates. SCL-A and SCL-B stains cloned from skin were used in the present study. The JK3 strain was cloned from the rotifer sample.

\section{Ciliate cultures}

YS1, WS1, YK1, JJ3 and Mie0301 isolated from the brain were subcultured in CHSE-214 cells after cloning, and grew to a titre of $\sim 10^{6}$ cells $\mathrm{ml}^{-1}$ in 5 to $7 \mathrm{~d}$ at $20^{\circ} \mathrm{C}$. These strains attached the anterior part of their cells to the flask bottom and actively lysed and destroyed CHSE-214 cells. The CHSE-214 cells finally detached from the bottom and floated in the medium. The ciliates fed on floating CHSE-214 cells, which finally disappeared in the culture flask within 5 to $7 \mathrm{~d}$.

Strains of SCL-A and SCL-B from skin ulcers did not multiply in a culture medium with CHSE-214 cells with a high concentration of antibiotics. SCL-A and SCL-B swam rapidly, floating in the medium, but did not consume or lyse CHSE-214 cells. The CHSE-214 cells retained their normal morphology. After cloning SCLA and SCL-B, antibiotics were reduced and coexisting bacteria were used as a food source. The ciliates grew to a titre of $\sim 10^{6}$ cells $\mathrm{ml}^{-1}$ in 5 to $7 \mathrm{~d}$ at $20^{\circ} \mathrm{C}$. Strains originating from the same fish, with SCL-A and SCL-B able to lyse CHSE-214 cells, were identified as Miamiensis avidus. These strains were maintained in the CHSE-214 cells but were not included in the present study.

The JK3 isolate that originated from rotifers swam in the medium but did not lyse CHSE-214 cells. Growth was poor in CHSE-214 cells. After cloning, JK3 was cultured in sterile Miliport $\mathrm{S}$ (258.6 mM NaCl, $12.3 \mathrm{mM}$ $\mathrm{MgCl}_{2} \cdot 6 \mathrm{H}_{2} \mathrm{O}, 5.3 \mathrm{mM} \mathrm{KCl}, 0.9 \mathrm{mM} \mathrm{CaSO}_{4}$ ) (Provasoli et al. 1957) containing $0.1 \%$ of BHIA, and coexisting bacteria were used as food. The ciliates numbered $\sim 10^{5}$ cells $\mathrm{ml}^{-1}$ after 5 to $7 \mathrm{~d}$ at $20^{\circ} \mathrm{C}$. Food source bacteria in ciliate culture did not grow in Salmonella Shigella agar (SS agar) (Difco) or thiosulfate citrate bile salts-sucrose (TCBS) agar (DifCo). No further identification of the bacteria was made.

\section{Identification}

Strains of YS1, YK1 and WS1 were identified as Miamiensis avidus by silver stain (Table 3) and sequencing of the SSU rRNA gene (Jung et al. 2005). YS1, YK1 and WS1 exhibited the same morphology; detailed morphology of the YS1 strain has been reported previously (Jung et al. 2007). Mie0301 and JJ3 were identified as $M$. avidus only by sequencing of the SSU rRNA gene. All 5 strains of $M$. avidus, YS1, YK1, WS1, Mie0301 and JJ3, exhibited the same 1759 bp of SSU rRNA sequences as deposited in GenBank (accession no. AY550080). SCL-A and SCL-B were identified as Pseudocohnilembus persalinus and $P$. hargisi, respectively, by morphological similarities with other reports (Song \& Wilbert 2002, Ma et al. 
Table 3. Morphometric characteristics of the specimens used. M1, 2, 3: Membranelles 1, 2, 3; PM1, 2: anterior and posterior parts of the paroral membrane, respectively; CVP: contractile vacuole pore. Data presented as means (range). All measurements in $\mu m$

\begin{tabular}{|c|c|c|c|c|}
\hline Character & $\begin{array}{l}\text { Miamiensis } \\
\text { avidus } \\
\text { YS1 strain }\end{array}$ & $\begin{array}{c}\text { Pseudocohnilembus } \\
\text { persalinus } \\
\text { SCL-A strain }\end{array}$ & $\begin{array}{c}\text { Pseudocohnilembus } \\
\text { hargisi } \\
\text { SCL-B strain }\end{array}$ & $\begin{array}{l}\text { Uronema } \\
\text { marinum } \\
\text { JK3 strain }\end{array}$ \\
\hline \multicolumn{5}{|l|}{ Body dimensions } \\
\hline Body length & $31.5(21-37)$ & $26.3(23.0-30.0)$ & $36.3(28.0-44.0)$ & $33(19.0-45.0)$ \\
\hline Body width & $18.5(11-28)$ & $11.5(9.3-14.0)$ & $13.9(8.8-18.0)$ & $12(9.0-27.0)$ \\
\hline \multicolumn{5}{|l|}{ Size of nuclei } \\
\hline Macronucleus & $6.3(3.9-6.6)$ & $6.7(5.7-8.4)$ & $8.7(7.6-9.8)$ & $4.8(3.2-5.9)$ \\
\hline Micronucleus & $1.55(1.2-2.4)$ & & $3.4(2.5-4.0)$ & \\
\hline \multicolumn{5}{|l|}{ Somatic cilia } \\
\hline Total no. kineties & $13(13-14)$ & $10(9-10)$ & $13(13-14)$ & $15(13-16)$ \\
\hline \multicolumn{5}{|l|}{ Oral ciliature } \\
\hline Distance from apex to M1 & $3.55(2.6-4.8)$ & & & \\
\hline Length of buccal field & $12.50(8.9-16.0)$ & $13.8(11.0-15.0)$ & $20.6(16.0-25.0)$ & $11.3(8.6-15.0)$ \\
\hline Length of PM & $\begin{array}{l}2.90(1.6-3.6)(\mathrm{PM} 1)^{\mathrm{b}} \\
4.60(2.6-5.4)(\mathrm{PM} 2)\end{array}$ & $6.6(5.0-8.0)$ & $9.5(7.4-12)$ & $7.5(5.0-7.0)$ \\
\hline Length of M1 & $2.15(1.6-2.7)$ & $6.6(5.5-7.9)$ & $11.3(7.1-16.0)$ & $1.7(1.2-2.5)$ \\
\hline Length of M2 & $2.60(1.5-4.5)$ & $9.4(9.2-11)$ & $17.3(13.2-22.3)$ & $1.6(1.2-3.2)$ \\
\hline Length of M3 & $0.69(0.56-0.85)$ & $1.2(0.9-1.6)$ & $1.5(0.8-2.0)$ & $1.1(0.9-1.7)$ \\
\hline Position of CVP & End of kinety 2 & End of kinety 3 & End of kineties 4 \& 5 & End of kinety 2 \\
\hline $\begin{array}{l}\text { aData from Jung et al. (2007) } \\
\text { bDiscrete with PM1 and PM2 }\end{array}$ & & & & \\
\hline
\end{tabular}

2003, Kim et al. 2004b) (Table 3) and SSU rRNA gene sequencing. SCL-A and SCL-B exhibited 98.9 and 99.9\% homology with deposited sequences of $P$. persalinus (AY551906) and P. hargisi (AY212806), respectively. JK3 was confirmed as Uronema marinum by morphological similarity with previous reports (Thompson 1963, Coppellotti 1990) (Table 3) and by its SSU rRNA genes, which had 99.6\% homology with a deposited sequence (GenBank accession no. Z22881). The SSU rRNA gene sequences of $P$. persalinus, $P$. hargisi and $U$. marinum determined in the present study were deposited in GenBank under accession numbers AY835669, AY833087 and DQ867074, respectively.

\section{Infection experiment: intraperitoneal injection}

The cumulative mortality of the fish by intraperitoneal injection with each species is shown in Fig. 1. Mortality was significantly higher $(p<0.0001)$ in the Miamiensis avidus (JJ3, WS1, YS1 and YK1)-infected group compared with the control. More than $80 \%$ of mortalities recorded in all the groups injected with $M$. avidus at a dose of $10^{6}$ cells fish ${ }^{-1}$ occurred within $7 \mathrm{~d}$ post-injection. The cumulative mortality of the Pseudocohnilembus persalinus (SCL-A)-infected group was $25 \%$ ( $\mathrm{p}=0.0183)$. P. hargisi (SCL-B)- and Uronema marinum (JK3)-infected groups showed no significant differences with the control group (Fig. 1A). Ciliates were observed in a wet mount preparation of the mori- bund and dead fish in all $M$. avidus-infected groups but not in other groups. No mortality was observed in the control group.

In the groups injected with $10^{4}$ cells fish $^{-1}$, the mortalities ranged from 10 to $45 \%$ in fish injected with Miamiensis avidus. No mortality was recorded in the remaining groups, including the control group (Fig. 1B).

\section{Infection experiment: immersion}

The cumulative mortalities of fish infected with each species are shown in Fig. 2. For the strains YS1, WS1, YK1 and JJ3 of Miamiensis avidus, mortality commenced between 6 and $9 \mathrm{~d}$ post-immersion, and reached $100 \%$ by $16 \mathrm{~d}$ in YK1-infected fish. The cumulative mortality for YS1 and JJ3 was $85 \%$ and for WS1 was $80 \%$ at the end of the $20 \mathrm{~d}$ infection period. $M$. avidus-infected groups showed significantly higher mortalities ( $p \leq 0.0005)$ than the control group. However, the cumulative mortalities of fish immersed with Pseudocohnilembus persalinus and P. hargisi was only $10 \%$ with no significant differences from the control for the duration of the infection experiment. No mortality was recorded in the control fish for the duration of the experiment (Fig. 2A).

In the second immersion infection experiment, mortality was significantly higher in YK1, WS1, YS1, Mie0301 and JJ3 (p < 0.0231); fish exhibited 60 to $90 \%$ 


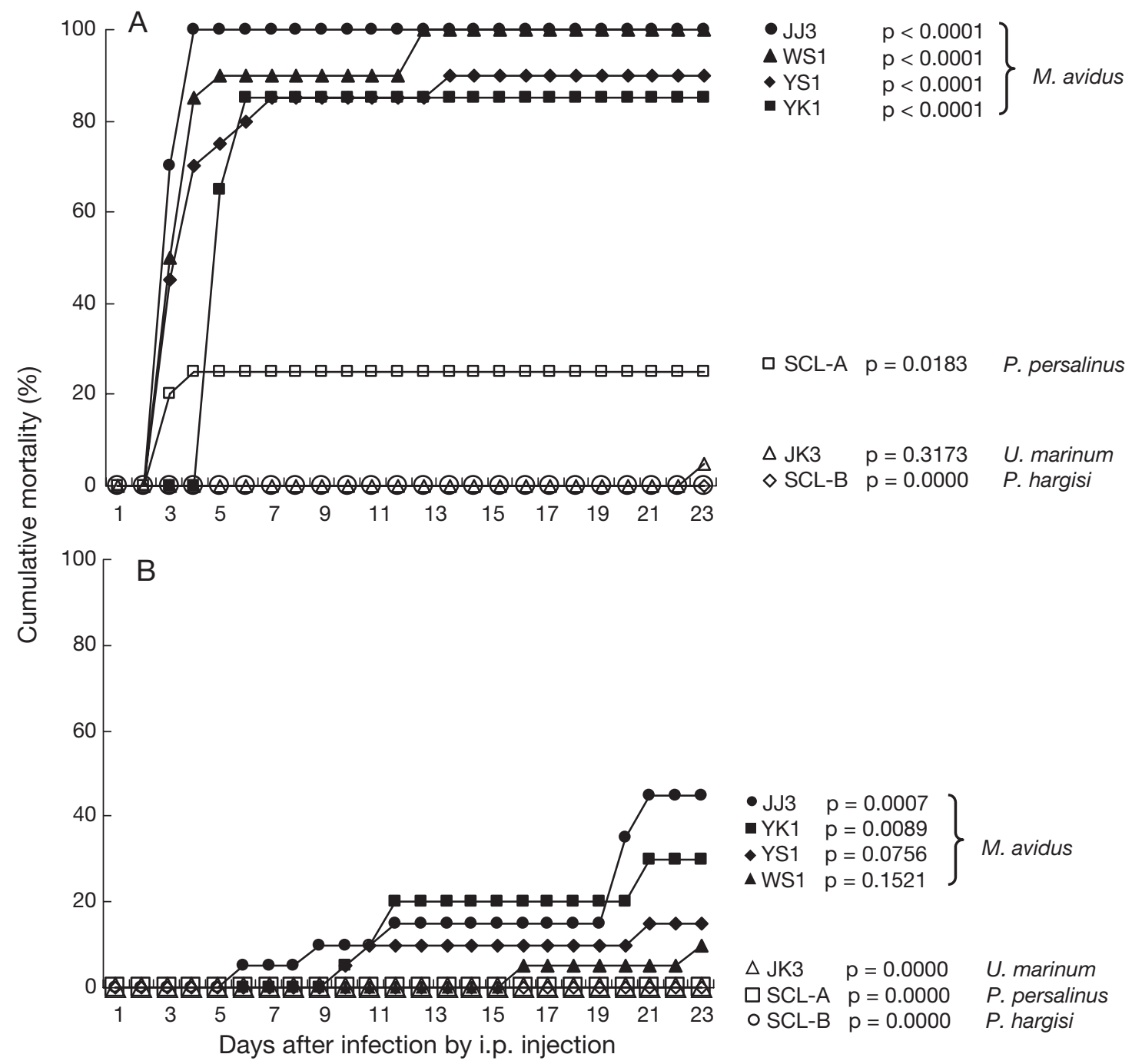

Fig. 1. Paralichthys olivaceus. Mortality patterns of olive flounder by the intraperitoneal (i.p.) injection route with Miamiensis

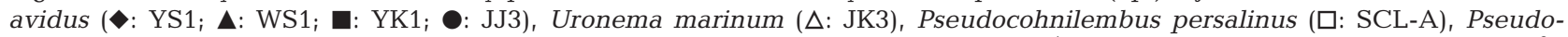
cohnilembus hargisi (O: SCL-B) and control $(\diamond)$. (A) Low infection dose $\left(1.0\right.$ to $\left.1.4 \times 10^{4}\right)$; (B) high infection dose $\left(1.0\right.$ to $\left.1.4 \times 10^{6}\right)$. Wilcoxon p-values are shown with strain names

mortality within $20 \mathrm{~d}$ compared with the Uronema marinum JK3 and control groups, which showed 30 and $20 \%$ mortality, respectively. No dead fish were observed in the Pseudocohnilembus persalinus- or $P$. hargisi-immersed groups (Fig. 2B). Statistical analysis showed no significant differences between $U$. marinum-, P. persalinus- and P. hargisi-infected groups with the control.

\section{Clinical signs}

For fish infected with Miamiensis avidus, i.p.-infected fish at a dose of $10^{6}$ ciliates fish ${ }^{-1}$ showed severe abdominal distension, dark body colour, increased opercula movement and convulsion, but no other skin lesions were observed (Fig. 3A). The ascetic fluid was red and large numbers of ciliates were swimming in the fluid. The intestine wall had become thin and transparent, and reddish fluid filled the intestine, and the liver and brain were red. In fish infected at a dose of $10^{4}$ ciliate fish ${ }^{-1}$, mortality occurred slowly and mild ulcer lesions were detected $19 \mathrm{~d}$ after infection. Most of the immersion-infected fish exhibited severe haemorrhages and ulcers on the fin, skin muscle and jaw (Fig. 3B). Fish took several days to die after ulcer lesions were observed. Haemorrhages in the intestine were rarely observed in the late phases of infection. Masses of ciliates were observed in the fins, skin, brain and gills in wet mount preparations. 


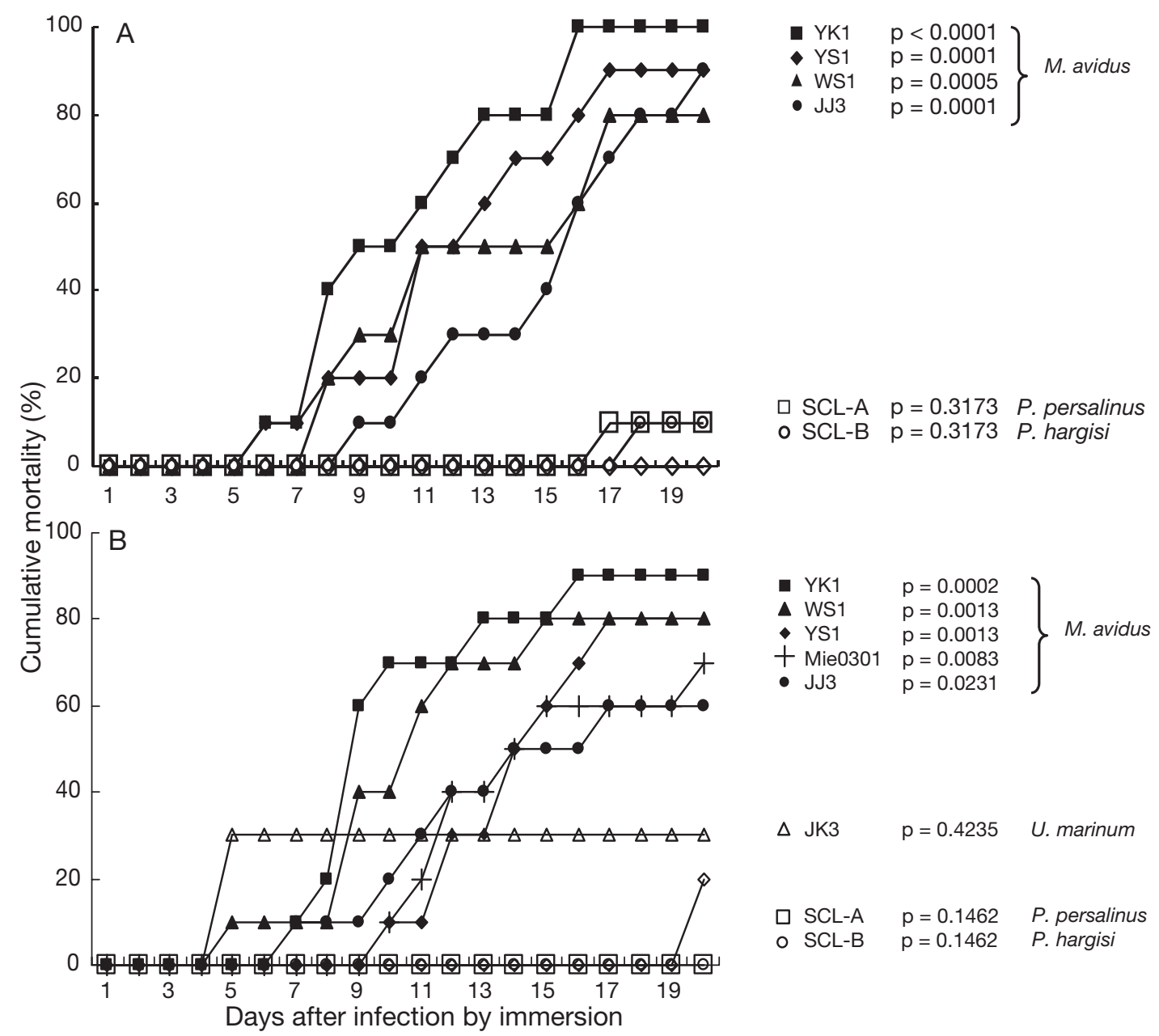

Fig. 2. Paralichthys olivaceus. Mortality patterns of olive flounder by the immersion route with Miamiensis avidus ( $\bullet$ : YS1; $\mathbf{\Delta}$ :

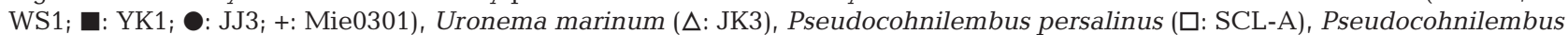
hargisi (O: SCL-B), and control $(\diamond)$. (A) First experimental infection with concentrations of 3.2 to $4.4 \times 10^{3} \mathrm{ml}^{-1}$. (B) Second experimental infection with concentrations of 2.6 to $5.2 \times 10^{3} \mathrm{ml}^{-1}$. Wilcoxon $\mathrm{p}$-values are shown with strain names
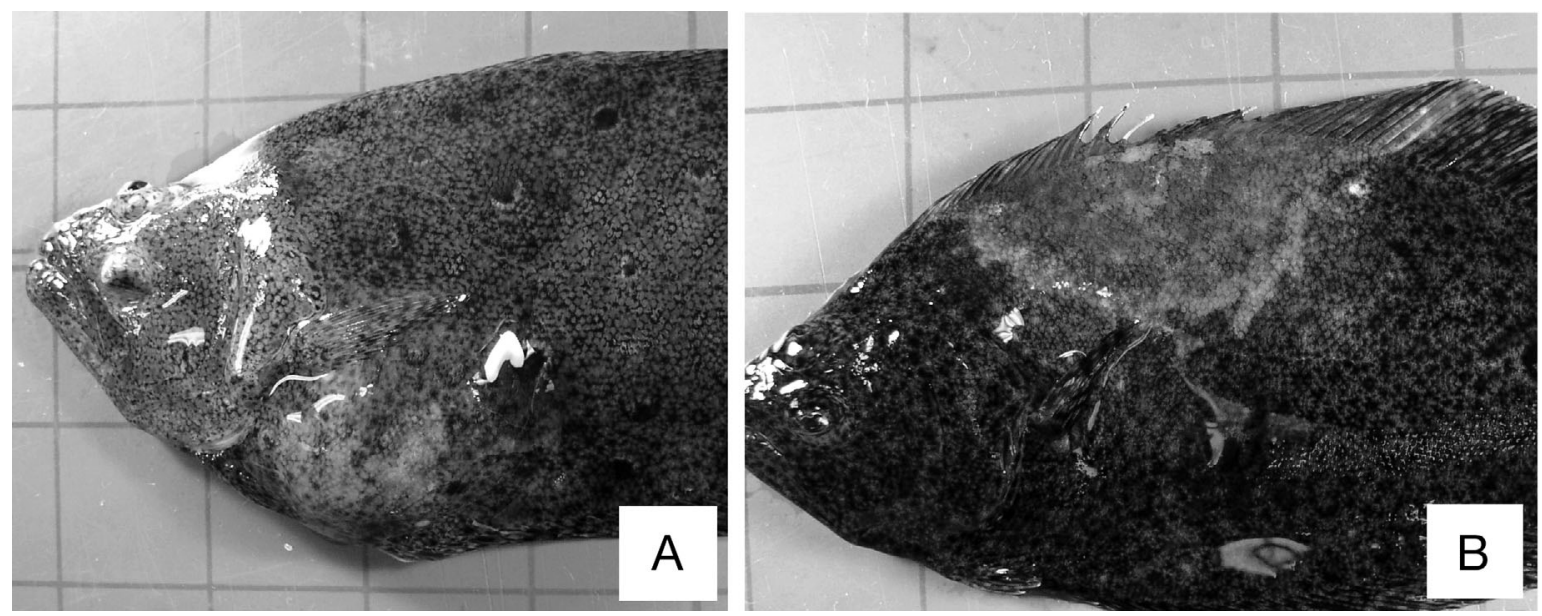

Fig. 3. Paralichthys olivaceus. Clinical signs of olive flounder experimentally infected with Miamiensis avidus. (A) Fish intraperitoneally injected with $1.4 \times 10^{4}$ cells of YS1 strain showing abdominal distension after $12 \mathrm{~d}$. (B) Fish infected by immersion with $3.8 \times 10^{3} \mathrm{cells} \mathrm{ml}^{-1}$ of JJ3 strain with severe skin ulcers after $14 \mathrm{~d}$ 
For fish infected with Pseudocohnilembus persalinus, P. hargisi. and Uronema marinum, besides having no symptoms of scuticociliatosis, no ciliates were seen in the fins, skin or gills in wet mount preparations.

\section{Histopathology}

All Miamiensis avidus strains of YS1, WS1, YK1, JJ3 and Mie 0301 caused the same histopathological changes in olive flounder. Many ciliates were observed in the blood vessels, gills, fins, skin muscle, brain and lamina propria of the digestive tract, accompanied by necrosis and haemorrhages (Fig. 4). There were no evident histopathological differences between the i.p.injected and immersion-infected groups of moribund and dead fish, except for severe necrosis and haemorrhage of the skin musculature in the immersioninfected group. However, no histological changes were observed in any tissues of fish infected with SCL-A (Pseudocohnilembus persalinus), SCL-B (Pseudocohnilembus hargisi) and JK3 (Uronema marinum), and there was no evidence of scuticociliates. In addition, bacteria were not observed in Giemsa-stained spleen, kidney or liver tissues at 1000× magnification.

\section{DISCUSSION}

Scuticociliatosis is a common disease in aquaculture fish, and in the last few years there have been several reports on fatal outbreaks of systemic infection by Philasterides dicentrarchi (syn. Miamiensis avidus) in sea bass, sea bream, turbot and olive flounder in France, Spain and Korea (Dragesco et al. 1995, Iglesias et al. 2001, Kim et al. 2004a, Jung et al. 2005). In addition, Uronema marinum and Pseudocohnilembus persalinus are also regarded as causative agents of scuticociliatosis in olive flounder (Cheung et al. 1980, Jee et al. 2001, Kim et al. 2004b). All the species reported are highly histophagous, causing skin ulceration and systemic infections of the brain, gills and digestive tract. In a previous study, we isolated 8 strains of scuticociliates from diseased olive flounder collected from different farms, and identified them as $M$. avidus by their complete SSU rRNA gene sequence (Jung et al. 2005) and morphological study of the YS1 strain (Jung et al. 2007).

In the present study, 2 other species of scuticociliatida were isolated from the ulcerated skin of diseased olive flounder, which was co-infected with Miamiensis avidus. They were identified as Pseudocohnilembus persalinus and $P$. hargisi by their complete SSU rRNA gene sequences and morphological characteristics. This is the first report of concurrent infection with different species of sucuticociliates in individual fishes.
However, it may commonly happen because many scuticociliates occur abundantly in coastal waters and at aquaculture sites (Yoshimizu et al. 1993, Song \& Wilbert 2000). In the case that different species of scuticociliates occur in a fish, careful observations and cloning steps are necessary for their in vitro culture, identification and characterization.

Pseudocohnilembus persalinus, P. hargisi and Uronema marinum exhibited differences from Miamiensis avidus in terms of their cell-lysing ability. M. avidus attached the anterior part of its cell to the flask bottom and actively lysed CHSE-214 cells, and the CHSE-214 cells finally detached from the bottom. However, $P$. persalinus and $P$. hargisi are bacteriophagous and did not lyse CHSE-214 cells. In addition, our U. marinum JK3 strain, originally isolated from rotifers, would not infect or kill rotifers, but only attached to dead rotifer cells in the bottom of the well in in vitro culture experiments (data not shown). U. marinum did not lyse CHSE-214 cells and the growth was not good in CHSE-214 cell culture conditions in EMEM with $10 \%$ FBS. U. marinum prefers the lower nutrient conditions of Miliport S containing $0.1 \%$ BHIA. Plunkett \& Hidu (1978) isolated $U$. marinum from diseased oysters and experimentally tested its growth in bacteria, algal cells and oyster tissue. U. marinum is bacteriophagous and not histophagous, and they concluded that U. marinum could not be the primary oyster pathogen. Regarding fish cell destruction and/or lysis characteristics, $P$. persalinus, $P$. hargisi and $U$. marinum may not cause severe ulcers or potential systemic invasion. In vivo experimental infections also correspond with the results of in vitro culture characteristics. Although it was reported that $P$. persalinus and $U$. marinum cause scuticociliatosis in olive flounder and marine fish species (Cheung et al. 1980, Jee et al. 2001, Kim et al. 2004b), there was no virulence displayed by these species in infection experiments by either immersion or i.p. injection methods. Therefore, we consider that $P$. persalinus, $P$. hargisi and $U$. marinum are non-pathogenic, free-living, bacteriophagous and/or saprophagous ciliates that secondarily attached to olive flounder ulcer lesions originally produced by $M$. avidus infection or some other cause.

In the present study, the mortality rate of olive flounder depended upon the infectious dose; 85 to $100 \%$ mortalities were recorded in olive flounder infected with $10^{6}$ cells of Miamiensis avidus within $7 \mathrm{~d}$, and 15 to $45 \%$ in fish infected with $10^{4}$ cells by i.p. injection. Immersion infection was successful with 3.2 to $4.4 \times$ $10^{3}$ ciliates $\mathrm{ml}^{-1}$. Four isolates from different regions in Korea and one isolate from Japan caused the same clinical signs and mortality pattern. Statistical analysis of survival curves showed significantly high pathogenicity of $M$. avidus-infected groups $\left(10^{6}\right.$ ciliates 

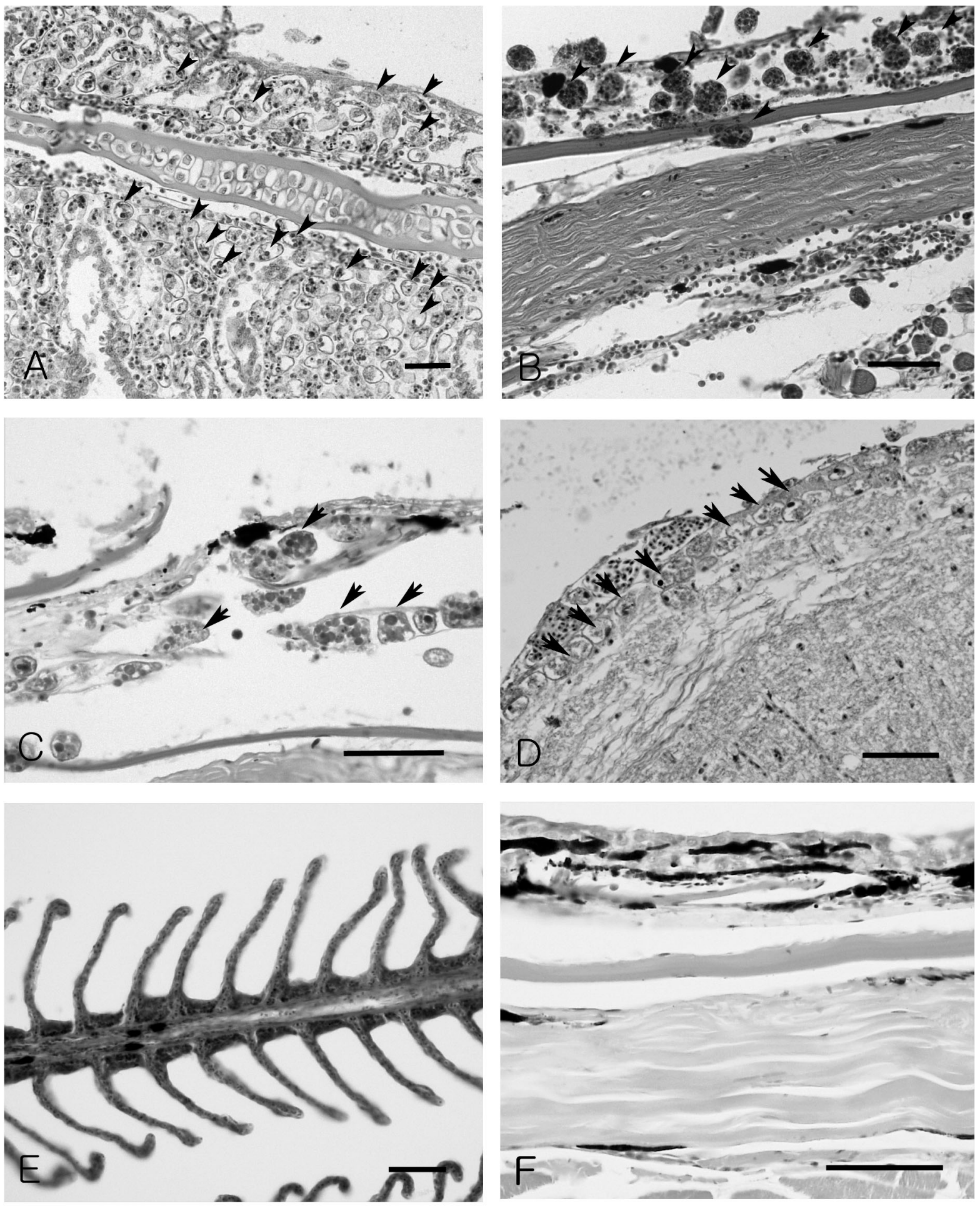

Fig. 4. Paralichthys olivaceus. Microscopic pathological changes in experimentally infected olive flounder by immersion with concentrations of 2.6 to $5.2 \times 10^{3} \mathrm{ml}^{-1}$. (A) Ciliates (arrowheads) in the gill with severe hyperplasia of the gill lamellae $13 \mathrm{~d}$ after YS1 infection at a concentration of $4.4 \times 10^{3} \mathrm{ml}^{-1}$. (B) Ciliates containing fish erythrocytes (arrowheads) in the dermis with haemorrhages and sloughed epidermis $9 \mathrm{~d}$ after WS1 infection at a concentration of $3.0 \times 10^{3} \mathrm{ml}^{-1}$. (C) Ciliates containing fish erythrocytes (arrowheads) in the dermis $14 \mathrm{~d}$ after JJ3 infection at a concentration of $3.8 \times 10^{3} \mathrm{ml}^{-1}$. (D) Ciliates (arrowheads) in the meninge of the brain $13 \mathrm{~d}$ after YS1 infection at a concentration of $4.4 \times 10^{3} \mathrm{ml}^{-1}$. (E) Gill infected with SCL-A at a concentration of $5.2 \times 10^{3} \mathrm{ml}^{-1} 20 \mathrm{~d}$ after infection with no histological change. (F) Skin infected with SCL-B at a concentration of $3.4 \times 10^{3} \mathrm{ml}^{-1}$ $20 \mathrm{~d}$ after infection, showing no histological change. All scale bars $=50 \mu \mathrm{m}$ 
fish $^{-1}$ i.p.-injected and $10^{3}$ ciliates $\mathrm{ml}^{-1}$ immersioninfected) compared with the control. Prominent differences of clinical signs according to the infection route are abdominal distension in i.p.-injected fish and ulcer lesions in immersion-infected fish. Clinical signs of natural infection were more similar to those in immersion infection than those in infection by injection, and natural infection may occur in a similar manner to immersion infection. Histological changes, infection routes and comparison with other studies in terms of pathogenicity are discussed in our previous study (Jung et al. 2007).

Alvarez-Pellitero et al. (2004) reported differences in virulence of Philasterides Kahl 1931 or Miamiensis Thomson et Moewus 1964 parasitizing turbot after long-term in vitro cultures. Isolate A was attenuated and isolate B was more virulent after 20 to 42 passages. In 2 yr of in vitro culture of Uronema marinum, significant decreases in protease activity and antioxidative enzymes were exhibited, and the authors suggested reduced protease activity might reflect infectivity to the host (Kwon et al. 2003). In contrast, long-term in vitro culture did not affect pathogenicity in the present study. The strain YS1, originally isolated in May 1999, exhibited the same strong pathogenicity as other isolates from 2003 and 2004. Although more evidence is needed, culture conditions of feeding live cells in the present study can be a factor maintaining their histolytic ability for pathogenicity.

Pseudocohnilembus persalinus, P. hargisi and Uronema marinum were cultured with food source bacteria, and these bacteria were included with ciliates for the infection trials. These food source bacteria seem unrelated to the fish mortality in our experimental conditions because the mortality of $P$. persalinus-, $P$. hargisi- and $U$. marinum-infected groups containing these bacteria exhibited no significant difference in survival to the control groups. Moreover, bacteria were not observed in fish tissue, which showed no histopathological changes.

Miamiensis avidus and Uronema marinum share similar morphometric characteristics in terms of body dimension, number of somatic cilia, position of contractile vacuole pores and oral ciliature. A major morphological difference between these 2 species is a pointed anterior with cilia in $M$. avidus and a flattened anterior apex without cilia in $U$. marinum. U. marinum was reported by Cheung et al. (1980) and Jee et al. (2001) as having a pointed anterior part where all the meridians reached the anterior end except for a shortened last somatic kinety (meridian), which ends membranelle 1 (M1). These morphological characteristics are the same as $M$. avidus. Although various silver impregnation methods have been used to identify scuticociliatida (Corliss 1953, Foissner 1991), there is diffi- culty in identification of various marine scuticociliates. Song \& Wilbert (2000) re-identified various marine scuticociliates and reported that 14 forms had been misidentified or were junior synonyms. SSU rRNA sequences have corroborated taxonomic relationships with morphological characters; these sequences may also be needed to confirm species identification among morphologically very similar species.

In conclusion, only Miamiensis avidus was pathogenic to olive flounder in experimental infections by the routes of i.p. injection and immersion. Pseudocohnilembus persalinus, $P$. hargisi and Uronema marinum did not show pathogenicity, suggesting that these species are not the main causative agent of scuticociliatosis in olive flounder.

Acknowledgements. This research was supported by the Ministry of Information and Communication, Korea, under the Information Technology Research Center support program supervised by the Institute of Information Technology Advancement (IITA-2007-C1090-0701-0001)

\section{LITERATURE CITED}

Alvarez-Pellitero P, Palenzuela O, Padrós F, Sitjà-Bobadilla A, Riaza A, Silva R, Arán J (2004) Histophagous scuticociliatids (Ciliophora) parasitizing turbot Scophthalmus maximus: morphology, in vitro culture and virulence. Folia Parasitol (Praha) 51:177-187

Azad IS, Al-Marzouk A, James CM, Almatar S, Al-Gharabally H (2007) Scuticociliatosis-associated mortalities and histopathology of natural infection in cultured silver pomfret (Pampus argenteus Euphrasen) in Kuwait. Aquaculture 262:202-210

Cheung PJ, Nigrelli RF, Ruggieri GD (1980) Studies on the morphology of Uronema marinum Dujardin (Ciliatea: Uronematidae) with description of histology of the infection in marine fishes. J Fish Dis 3:295-303

Chun SK (2000) Scuticociliatosis, disease of cultured and marine fish. Hanguk Susan Sinbo Press, Seoul (in Korean)

Coppellotti O (1990) Description of Uronema marinum (Ciliophora, Scuticociliatida) from the Antarctica and observations on the nuclear events in conjugation. Polar Biol 10:365-371

Corliss JO (1953) Silver impregnation of ciliated protozoa by the Chatton-Lwoff technique. Stain Technol 28:97-100

Dragesco A, Dragesco J, Coste F, Gasc C, Romestand B, Raymond J, Bouix G (1995) Philasterides dicentrarchi, n. sp. (Ciliophora, Scuticociliatida), a histophagous opportunistic parasite of Dicentarchus labrax (Linnaeus, 1758), a reared marine fish. Eur J Protistol 31:327-340

> Dyková I, Figueras A (1994) Histopathological changes in turbot Scophthalmus maximus due to a histophagous ciliate. Dis Aquat Org 18:5-9

Foissner W (1991) Basic light and scanning electron microscopic methods for taxonomic studies of ciliated protozoa. Eur J Protistol 27:313-330

Goding JW (ed) (1993) Production of monoclonal antibodies. In: Monoclonal antibodies: principles and practice. Academic Press, London, p 175-176

> Iglesias R, Paramá A, Alvarez MF, Leiro J, Fernández J, Sanmartin ML (2001) Philasterides dicentrarchi (Ciliophora, 
Scuticociliatida) as the causative agent of scuticociliatosis in farmed turbot Scophthalmus maximus in Galicia (NW Spain). Dis Aquat Org 46:47-55

Jee BY, Kim YC, Park MS (2001) Morphology and biology of parasite responsible for scuticociliatosis of cultured olive flounder Paralichthys olivaceus. Dis Aquat Org 47:49-55

> Jung SJ, Kitamura SI, Song JY, Joung IY, Oh MJ (2005) Complete small subunit rRNA gene sequence of the scuticociliate Miamiensis avidus pathogenic to olive flounder Paralichthys olivaceus. Dis Aquat Org 64:159-162

Jung SJ, Kitamura SI, Song JY, Oh MJ (2007) Miamiensis avidus (Ciliophora: Scuticociliatida) causes systemic infection of olive flounder Paralichthys olivaceus and is a senior synonym of Philasterides dicentrarchi. Dis Aquat Org 73:227-234

Kim SM, Cho JB, Lee EH, Kwon SR, Kim SK, Nam YK, Kim $\mathrm{KH}$ (2004a) Occurrence of scuticociliatosis in olive flounder Paralichthys olivaceus by Philasterides dicentrarchi (Ciliophora: Scuticociliatida). Dis Aquat Org 62:233-238

Kim SM, Cho JB, Lee EH, Kwon SR, Kim SK, Nam YK, Kim KH (2004b) Pseudocohnilembus persalinus (Ciliophora: Scuticociitida) is an additional species causing scuticociliatosis in olive flounder Paralichthys olivaceus. Dis Aquat Org 62:239-244

Kwon SR, Kim CS, Kim KH (2003) Differences between shortand long-term cultures of Uronema marinum (Ciliophora: Scuticociliatida) in chemiluminescence inhibitory activity, antioxidative enzyme and protease activity. Aquaculture 221:107-114

Ma H, Song W, Hu X, Warren A (2003) Morphology and stomatogenesis of Pseudocohnilembus hargisi (Ciliophora: Scuticociliatida). J Mar Biol Assoc UK 83:399-405

Munday BL, O'Donoghue PJ, Watts M, Rough K, Hawkesford $\mathrm{T}$ (1997) Fatal encephalitis due to the scuticociliata Uronema nigricans in sea-caged, southern bluefin tuna Thunnus maccoyii. Dis Aquat Org 30:17-25

Editorial responsibility: Dieter Steinhagen,

Hannover, Germany
Plunkett L, Hidu H (1978) The role of Uronema marinum (Protozoa) in oyster hatchery production. Aquaculture 15: 219-235

> Provasoli L, McLaughlin JJA, Droop MR (1957) The development of artificial media for marine algae. Arch Mikrobiol 25:392-428

> Puig L, Traveset R, Palenzuela O, Padrós F (2007) Histopathology of experimental scuticociliatosis in turbot Scophthalmus maximus. Dis Aquat Org 76:131-140

Song W, Wilbert N (2000) Redefinition and redescription of some marine scuticociliates from China, with report of a new species, Metanophrys sinensis nov. spec. (Ciliophora, Scuticociliatida). Zool Anz 239:45-74

> Song W, Wilbert N (2002) Reinvestigations of three 'wellknown' marine scuticociliates: Uronemella filificum (Kahl, 1931) nov. gen., nov. comb., Pseudocohnilembus hargisi Evans \& Thompson, 1964 and Cyclidium citrullus Cohn 1865, with description of the new genus Uronemella (Protozoa, Ciliophora, Scuticociliatida). Zool Anz 241:317-331

> Sterud E, Hansen MK, Mo TA (2000) Systemic infection with Uronema-like ciliates in farmed turbot Scophthalmus maximus (L.). J Fish Dis 23:33-37

Thompson JC (1963) A redescription of Uronema marinum, and a proposed new family Uronematidae. Va J Sci 15: 80-87

Thompson JC, Moewus L (1964) Miamiensis avidus n. g., n. sp., a marine facultative parasite in the ciliate order Hymenostomatida. J Protozool 11:378-381

Yoshimizu M, Hyuuga S, Oh MJ, Ikoma M and others (1993) Scuticociliatida infection of cultured Hirame (Paralichthys olivaceus). Fish Pathol 6:205-218 (in Japanese)

Yoshinaga T, Nakazoe J (1993) Isolation and in vitro cultivation of an unidentified ciliate causing scuticociliatosis in Japanese flounder (Paralichthys olivaceus). Fish Pathol 28:131-134

Submitted: October 9, 2007; Accepted: November 28, 2008 Proofs received from author(s): February 9, 2009 